\title{
Complete Remission by Primary Chemotherapy of Advanced Non-Seminomatous Germ Cell Tumor in an Intra-Abdominal Testis
}

\author{
Pierre Sarkis, Hampig Raphael Kourie, Joseph Gharios, Joseph Kattan \\ Saint-Joseph Hospital, Raymond and Aida Najjar Medical Center, Saint-Joseph University, Beirut, Lebanon \\ Email: plsarkis@inco.com.lb, hampig.kourie@hotmail.com, joseph.gharios@hotmail.com, \\ jkattan62@hotmail.com
}

Received 14 June 2014; revised 15 July 2014; accepted 6 August 2014

Copyright $@ 2014$ by authors and Scientific Research Publishing Inc. This work is licensed under the Creative Commons Attribution International License (CC BY). http://creativecommons.org/licenses/by/4.0/ (c) (i) Open Access

\begin{abstract}
Ectopic testis predisposes to a high risk of germ cell tumor development. Treatment of advanced testicular germ cell tumor developing in an uncorrected abdominal testis is based on primary chemotherapy followed by removal of the testis along with residual masses. However, persistence of viable tumor particularly in the testis is always noted since testis penetration of chemotherapeutic agents is reduced. We report a case of complete pathological remission of a patient with advanced non-seminomatous germ cell tumor in intra-abdominal testis by primary chemotherapy alone, with a review of the literature.
\end{abstract}

\section{Keywords}

Germ Cell Tumors, Intra-Abdominal Testis, Non-Seminomatous Germ Cell Tumors

\section{Introduction}

Germ cell tumors of the testis (GCT) have their highest incidence in young adults. One of the most important factors that increase GCT occurrence is cryptorchidism [1], with a relative risk of 2.75 to 8 [2]. The risk of developing testicular cancer is affected by the location of the undescended testis, in a way that inguinal testes are four times less likely to become cancerous compared with intra-abdominal testes [3].

Nowadays, the existence of undescended testis in the adult population is rare, since elective orchiopexy is universally practiced before the second year of life to prevent infertility [4]. Malignant transformation of uncor- 
rected undescended testis is rarely discussed in the literature. Treatment of advanced tumors in these testes is based on primary chemotherapy followed by surgery of all residual masses. However, obtaining complete remission by primary chemotherapy, especially in the primary testis which is considered a sanctuary, is almost unrealizable [5].

We reported here a case of advanced GCT in a neglected cryptorchid testis in a 40-year-old man where primary cisplatin-based chemotherapy resulted in a pathological and sustained complete remission confirmed by secondary surgery and follow-up.

\section{Clinical Case}

A 40-year-old married man, heavy smoker, with a known history of neglected left cryptorchidism presented for lumbar pain with a palpable low pelvic mass. An abdominal and pelvic computed tomography (CT) showed a pelvic mass $(10 \times 15 \mathrm{~cm})$ with retroperitoneal enlarged lymph nodes, the largest measuring $4 \mathrm{~cm}$ (Figure 1). Tumor was therefore classified as IIB according to TNM staging. A percutaneous biopsy of the mass revealed non-seminomatous germ cell tumor (NSGCT) including embryonal carcinoma. Initial tumor markers showed elevated alpha foetoprotein (AFP) with a rate of $136 \mathrm{IU} / \mathrm{ml}$, elevated B-human chorionic gonadotrophin (B-HCG) at $2465 \mathrm{IU} / \mathrm{ml}$, and elevated lactate dehydrogenase (LDH) at 628 (normal value $240 \mathrm{IU}$ ). Chest and cerebral CT were unremarkable.

The disease was considered an intermediate risk according to International Germ Cell Consensus Classification (IGCCC) [6]. He received 4 cycles of Cisplatinum at a dosage of $20 \mathrm{mg} / \mathrm{m}^{2}$, VP16 at $100 \mathrm{mg} / \mathrm{m}^{2}$ day 1 to 5 and Bleomycin $30 \mathrm{mg}$ on days 1, 8 and 15 (BEP regimen). Normalization of tumor markers was achieved at the second cycle with a non logarithmic level decrease (Table 1).

Tumor assessment after 4 cycles of BEP showed a regression of the pelvic mass to $10.8 \times 6 \mathrm{~cm}$ and an almost complete regression of regional lymph nodes (Figure 2). A complete resection of the primary capsulated pelvic mass was done, as well as a hard resection and dissection of the lymphatic magma infiltrating the intestine, the bladder, and the para-aortic vessels. Histology failed to find any viable tumor cells, and the whole resected tissue contained only necrosis. Two years after surgery, disease assessment by CT (Figure 3) and tumor markers confirmed maintenance of complete remission. Moreover, the patient has normal ejaculation, while the sperm analysis showed persistent azoospermia.

\section{Discussion}

Germ cell tumors are considered today the concrete and relevant example of a sensitive and curable neoplasm by chemotherapy [7]. Treatment of stage I localized NSGCT is orchiectomy by inguinal incision with adjuvant chemotherapy, if indicated, according to vascular invasion in the removed primary tumor and normalization of tumor markers (alpha-FP, beta-HCG, LDH) after orchiectomy [6]. In advanced settings, the standard treatment is orchiectomy followed by cisplatin-based combination chemotherapy and surgical resection of residual masses.

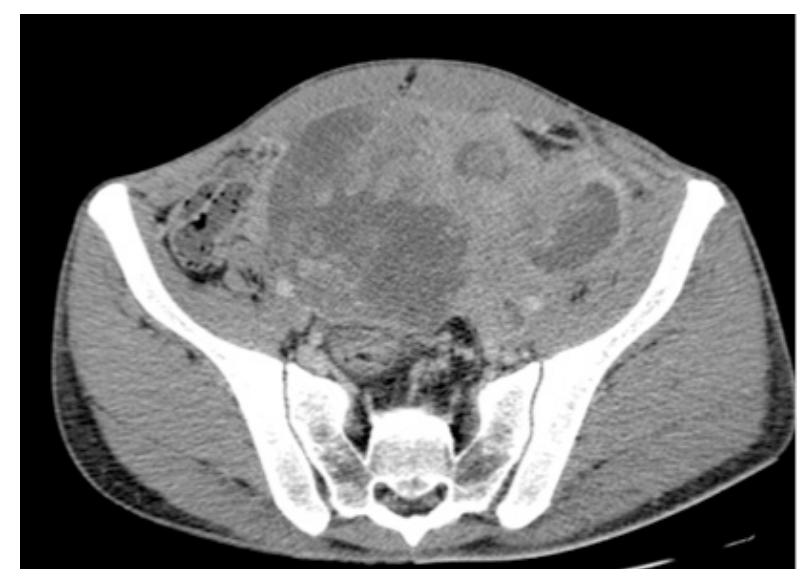

Figure 1. Pelvic CT scan shows a huge heterogeneous mass with enlarged pelvic nodes. 
Table 1. Tumor markers decrease after initiation of chemotherapy.

\begin{tabular}{cccccc}
\hline & \multicolumn{5}{c}{ Days after Chemotherapy } \\
\hline Tumor Markers & $\mathrm{d} 0$ & $\mathrm{~d} 11$ & $\mathrm{~d} 21$ & $\mathrm{~d} 31$ & $\mathrm{~d} 42$ \\
BHCG & 2201 & 830 & 90.5 & 14.86 & 4.9 \\
AFP & 163 & 154 & 52.3 & 19.6 & 9.2 \\
LDH & 628 & 388 & 271 & - & 185 \\
\hline
\end{tabular}

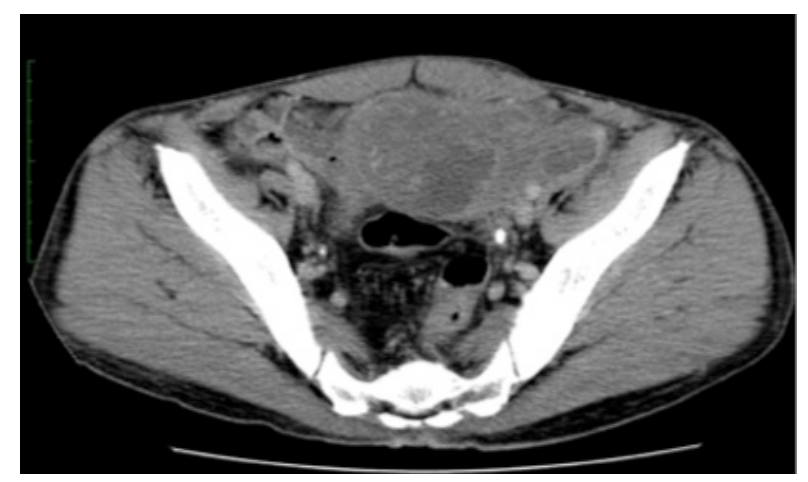

Figure 2. Tumor regression after four cycles of BEP.

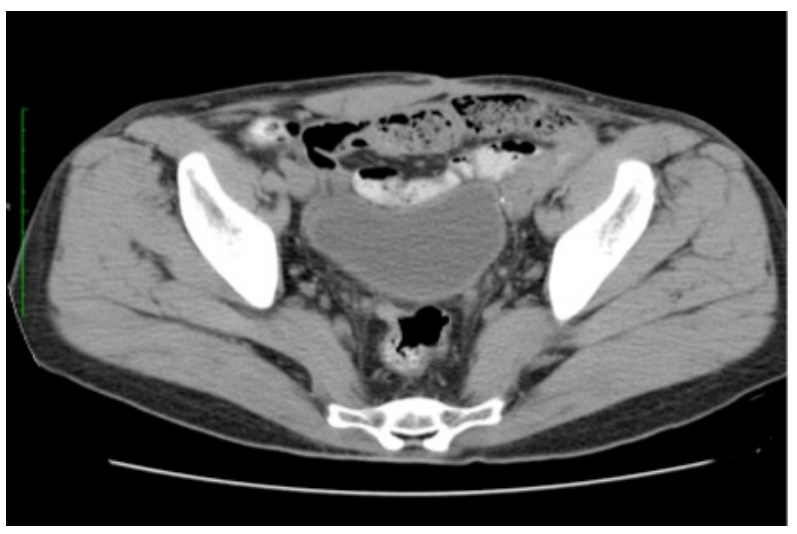

Figure 3. Absence of recurrence two years after surgery.

Cure rate in all combined stages is as high as 80\% [8].

In patients with advanced NSGCT, primary aggressive chemotherapy without removal of the primary tumor and sometimes without the need of tissue diagnosis may be considered. Benefit of this therapeutic approach is the immediate management of acute abdominal and/or pulmonary symptoms of life-threatening distant metastases in super high risk patients [9]. Another advantage of this approach is the possibility of surgical treatment of residual metastatic masses simultaneously with orchiectomy [10]. However, sanctuary sites such as testis are poorly penetrated by these pharmacologic agents. The blood-testis barrier is considered to be the explanation of persistent of residual tumor within the gonad after chemotherapy [11]. Thus, orchiectomy has an important role in the treatment of testicular cancer either localized or metastatic [12]. While many studies proved that the primary tumor in testicular cancer should be removed in patients presenting initially with metastatic disease, delayed orchiectomy was found as effective as primary orchiectomy by some authors [13], and thus sanctuary theory was again reconsidered.

Our case represents an advanced intra-abdominal NSGCT of intermediate risk according to IGCCC criteria. The first line treatment in this case was based on BEP chemotherapy, since the surgical removal of the primary intra-abdominal undescended testis with bulky retroperitoneal metastasis was considered to be technically hazardous. The chemotherapy was followed by removal of the primary tumor and residual tissues once tumor 
markers normalized after the first line chemotherapy [14]. Histopathological study failed to show any viable tumor neither in the testis nor in the residual masses, but only necrosis.

We believe that our patient represents the first case where a complete necrosis was obtained by primary chemotherapy in an undescended intra-abdominal germ cell tumor. Moreover, the remission was sustained, which was unexpected according to the unfavorable marker decrease. This brilliant outcome is against the sanctuary theory on one hand, whereas the nonlogarythmic decrease is in favor of it on the other hand [15].

\section{Conclusion}

The presence of advanced NSGCT in uncorrected abdominal testis does not preclude the use of primary chemotherapy before orchiectomy. Complete remission of the disease may be achieved by this approach and raise the question of the validity of the sanctuary theory which considers that chemotherapeutic agents are not efficient within the primary tumor.

\section{References}

[1] Kuo, J.Y., Huang, W.J., Chiu, A.W., Chen, K.K. and Chang, L.S. (1999) Clinical Experiences of Germ Cell Tumor in Cryptorchid Testis. The Kaohsiung Journal of Medical Sciences, 15, 32-37.

[2] Wood, H.M. and Elder, J.S. (2009) Cryptorchidism and Testicular Cancer: Separating Fact from Fiction. The Journal of Urology, 181, 452-461. http://dx.doi.org/10.1016/j.juro.2008.10.074

[3] Batata, M.A., Chu, F.C., Hilaris, B.S., Whitmore, W.F. and Golbey, R.B. (1982) Testicular Cancer in Cryptorchids. Cancer, 49, 1023-1030. http://dx.doi.org/10.1002/1097-0142(19820301)49:5<1023::AID-CNCR2820490528>3.0.CO;2-M

[4] A.A., Darzi, Aliramaji, A. and Ramezani, M.S. (2010) Unresolved Abdominal Mass in an Adult Cryptorchid Testis: A Case Report. International Journal of General Medicine, 3, 395-398.

[5] Kuo, J.Y., Chiu, A.W., Chen, K.K. and Chang, L.S. (1999) Life-Threatening Germ Cell Tumor Arising in Cryptorchidism: A Case Report. Zhonghua Yi Xue Za Zhi (Taipei), 62, 116-120.

[6] International Germ Cell Cancer Collaborative Group (1997) International Germ Cell Consensus Classification: A Prognostic Factor-Based Staging System for Metastatic Germ Cell Cancers. Journal of Clinical Oncology, 15, 594603.

[7] Morelli, F., Tozzi, L., Setola, P., Bisceglia, M., Barbini, V.R. and Maiello, E. (2006) Postchemotherapy Residual Masses in Germ Cell Tumor Patients: Our Experience. Annals of Oncology, 17, 132-136. http://dx.doi.org/10.1093/annonc/mdl966

[8] Ries, L.A., Eisner, M.P., Kosary, C.L., et al. (2004) SEER Cancer Statistics Review, 1975-2001. National Cancer Institute, Bethesda, MD.

[9] Moran-Ribon, A., Droz, J.P., Kattan, J., Leclercq, B., Ghosn, M., Couanet, D., et al. (1994) Super-High-Risk GermCell Tumors: A Clinical Entity. Supportive Care in Cancer, 2, 253-258. http://dx.doi.org/10.1007/BF00365732

[10] Ondrus, D., Hornák, M, Breza, J., Mat’oska, J., Schnorrer, M., Belan, V., et al. (2001) Delayed Orchiectomy after Chemotherapy in Patients with Advanced Testicular Cancer. International Urology and Nephrology, 32, 665-667. http://dx.doi.org/10.1023/A:1014466110566

[11] Dave, D.S., Leppert, J.T. and Rajfer, J. (2007) Is the Testis a Chemo-Privileged Site? Is There a Blood-Testis Barrier? Reviews in Urology, 9, 28-32.

[12] James, P.P. and Mead, G.M. (1992) Sanctuary Site Relapse in Chemotherapy-Treated Testicular Cancer. Annals of Oncology, 3, 41-43.

[13] Snow, B.W., Rowland, R.G., Donohue, J.P., Einhorn, L.H. and Williams, S.D. (1983) Review of Delayed Orchiectomy in Patients with Disseminated Testis Tumors. Journal of Urology, 129, 522-523.

[14] Kulkarni, J.N., Desai, S.M., Phadke, G.K. and Tongaonkar, H.B. (1996) Improved Management of Abdominal Undescended Testicular tumors with Bulky Confluent Retroperitoneal Nodal Metastases. Journal of Urology, 156, 13411344. http://dx.doi.org/10.1016/S0022-5347(01)65582-4

[15] Fizazi, K., Culine, S., Kramar, A., Amato, R.J., Bouzy, J., Chen, I., et al. (2004) Early Predicted Time to Normalization of Tumor Markers Predicts Outcome in Poor-Prognosis Nonseminomatous Germ Cell Tumors. Journal of Clinical Oncology, 22, 3868-3876. http://dx.doi.org/10.1200/JCO.2004.04.008 
Scientific Research Publishing (SCIRP) is one of the largest Open Access journal publishers. It is currently publishing more than 200 open access, online, peer-reviewed journals covering a wide range of academic disciplines. SCIRP serves the worldwide academic communities and contributes to the progress and application of science with its publication.

Other selected journals from SCIRP are listed as below. Submit your manuscript to us via either submit@scirp.org or Online Submission Portal.
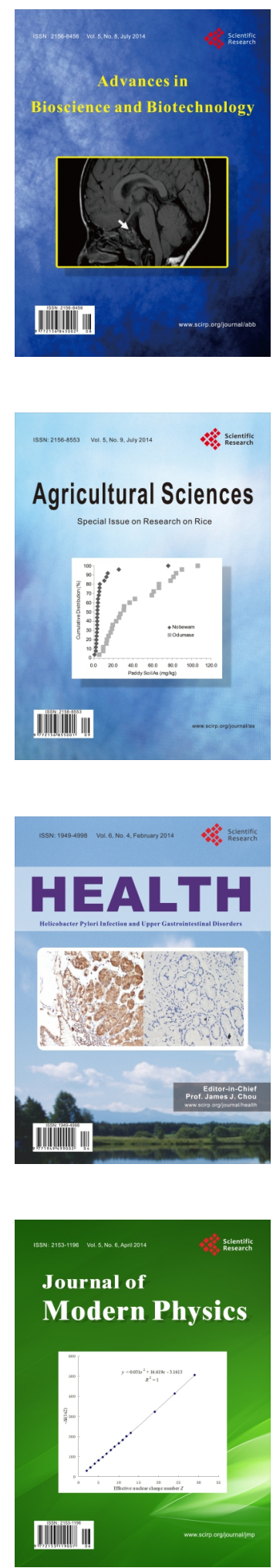
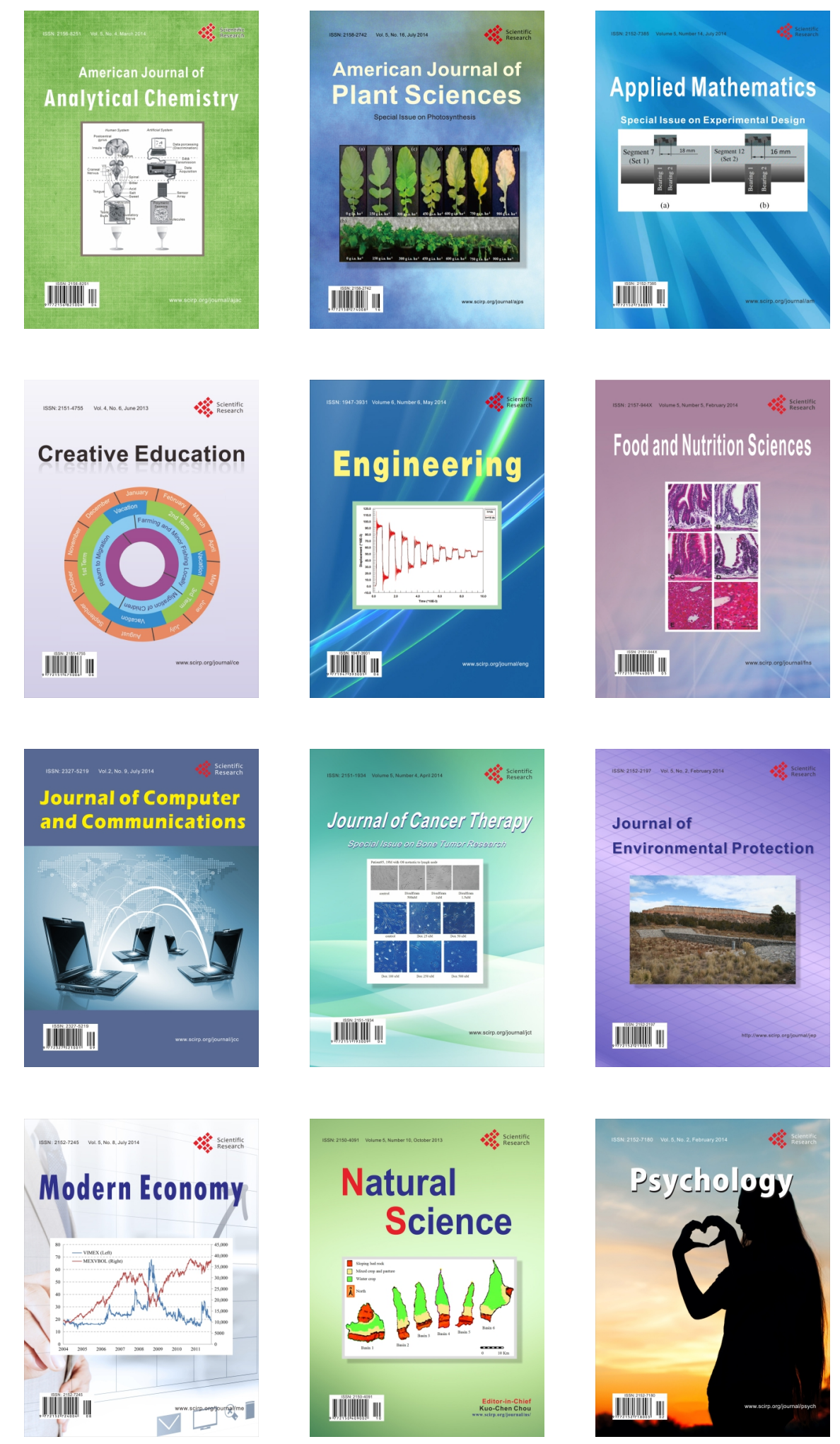